Daniela Stanojkovska, $\mathrm{PhD}$

PI Institute for Social Activities - Skopje

\title{
KNOWLEDGE OF PROFESSIONALS FOR PROVIDING SOCIAL SERVICES FOR OLD PEOPLE
}

\section{ABSTRACT}

Demographic aging, which is increasingly becoming a reality in the Republic of North Macedonia, brings challenges for the development of appropriate social services, according to the needs of the elderly, but also the need to acquire and deepen the knowledge of professionals who provide these services. All this is imposed as a need for one purpose and that is to meet the needs of the elderly.

The professional development of social protection professionals in the Republic of North Macedonia is part of a comprehensive process that seeks to follow European trends for continuous professional development. However, the fact that the development of social services for the elderly in North Macedonia follows experiences increased dynamics in recent years, and is expected to develop faster with the reformed social protection system from 2019, imposes the need to study the knowledge whereby professionals enter the provision of social services, as well as the need to expand and deepen them. This paper is aimed at studying the knowledge of professionals who provide social services to the elderly, and the results of quantitative research conducted with professionals, indicate the need to strengthen them during vocational education and the process of continuous professional development.

Keywords: knowledge, professionals, social services, the elderly

\section{INTRODUCTION}

Pearsall and Hanks (2003) in the Oxford Dictionary define knowledge as: "Facts, information and skills acquired through experience and education, theoretical and practical understanding of the subject" (Ohford Dictionary 2010: 967).

Trevithick conceives knowledge in a framework consisting of three areas:

- "theoretical knowledge or theories;

- factual knowledge (including research) and

- practice, practical or personal knowledge".

(Trevithick, 2009: 25)

All this points to the fact that knowledge has a theoretical significance and consists of scientific knowledge that is well systematized and generalized, and relates to a particular scientific field. That is why it is especially important for every professional to have knowledge, which will enable him/her to successfully realize 
the work tasks in his/her workplace. In addition, knowledge is very dynamic, because it is constantly moving and changing under the influence of the development of science, which imposes the need for constant investment in them as the most important human capital.

Social intervention with the elderly is often associated with gerontology and requires special knowledge of the aging process, which is based on biology, psychology and social sciences. Each of these perspectives enables the social worker to understand the aging process on a personal level and provides the foundation needed to understand the problems, risks and needs of the elderly.

The need for specific gerontological or geriatric knowledge was not recognized in social work until the mid-20th century. Before the fifties, social work with the elderly was not observed at all, while the late sixties and early seventies was a period when the elderly began to be recognized as a target group for social intervention. During this period, in essence, many professions began to recognize the need for specialized knowledge and training of people who need to provide professional support to the elderly.

The non-recognition of the elderly as a target group for social intervention has led for a long time to have a poor readiness of professionals to meet the needs of the aging population. Thus, if in the beginning the knowledge and skills for working with the elderly were provided for a very small number of students for social work, later the need was identified in addition to basic knowledge for social workers to have the opportunity to acquire specialized knowledge in this area. Thus, social workers should have knowledge of modern theoretical concepts and practices in the context of social work with the elderly and develop skills for their specific, practical work. They should also gain knowledge about working with people with dementia and people who need long-term care at home or in social care facilities for the elderly.

According to Damron-Rodriguez and Corley, Berkman et al. (2007; Berkman et al., 2007), the main areas of knowledge social workers need to work in the field of social intervention with the elderly are defined at the White House Conference on Aging, held in 1995: "Understanding Biopsychosocial Perspectives, the Family System, Life Stages, Advocacy, State Policies and Programs Affecting the Elderly, and Interdisciplinary Teamwork" (Gilmore, 2013: 18).

According to Damron-Rodriguez and Corley, Berkman, Rowan, Bures, Wilson et al., (Damron-Rodriguez and Corley, 2002; Berkman et al., 2007; Rowan et al., 2010; Bures at al., 2002; Wilson, 2006 ): "Social workers should have knowledge of the biopsychosocial factors relevant to the elderly, how to work in interdisciplinary teams, and resources specific to the needs of the elderly" (Ibid 1: p. 19).

Considering that old age and aging bring great heterogeneity in the daily life of the elderly and specific problems related to old age and aging, and that 2020 has left a special mark on the elderly facing 
the challenges of preserving their own health and quality of life in in the context of a pandemic, this paper is devoted to the study of the knowledge of professionals for social and health care for the elderly, as extremely necessary knowledge for the provision of social services for the elderly.

\section{KNOWLEDGE FOR THE SOCIAL AND HEALTH CARE OF THE ELDERLY}

\section{Knowledge for social protection} rights and services for the elderly. Knowledge of the social protection system, namely the rights and services intended for the elderly are crucial primarily for social workers, but also for any other professionals involved in social intervention with the elderly. Even the best assessment of the condition of the elderly and their family, of their needs and potentials is useless if professionals do not know what the services and rights of social protection that can alleviate or overcome the social risk of the elderly are. Knowledge of social protection rights and services is at the core of the social work profession. However, in addition to social security services, professionals working with the elderly must also have knowledge of health care rights and services, as old age and aging are risks that are closely linked to changes in the biopsychosocial functioning of the elderly.

Knowledge for social and health care resources and services is essentially an integral part of knowledge of working in the local community as a method of social intervention. "The social worker is the organizer of the local population. $\mathrm{He}$ discovers the problems, diagnoses them and solves them together with the local population" (Donevska, 2006: 67). The local community has a special meaning in the life of the elderly, because in it they usually meet most of their needs, and also because of their limited mobility and reduced economic power. The activities in the local community aimed at meeting the needs of the elderly by the social services are most often recognized as activities of social intervention, and very rarely as social integration. According to Donevska: "This is a really optimal solution, however, which requires, within the social assistance at the community level, to include a number of entities in the field of health, including rehabilitation, assistance in running households, etc." Ibid 1: p. 111). Therefore, closely related to the knowledge for working in the local community are the knowledge for mapping the services of social and health care, as well as the conditions for eligibility to use the services of social and health care.

Mapping of social and health care services and services. The elderly need to stay independent in their homes for as long as possible, and even when placed in institutions they need to maintain their independence as much as possible. According to Rowan et al. (2010; Bures et al., 2002): "In order to support the elderly, for as long as possible independence, social workers must have knowledge for programs of local, state and federally level, which are available to help seniors to 
achieve these goals, including financial, nutritional, health, and home care resources" (Gilmore, 2013).

Many older people spend their lives in their homes, actually, despite the limitations and difficulties that may occur with age, they still live in their natural environments. These elderly people need support from the resources in the environment, and social workers involved in social intervention as the elderly must have knowledge for the resources, or all service providers in their environment and beyond, who could meet the health and social needs of users. Only in this way professionals will be able to achieve the ultimate goal, which is connecting the elderly with the most appropriate services for them, at the moment. According to Rowan et al., 2010: "Social workers must have a deeper knowledge of planning and appropriate connection in accordance with eligibility with providers (organizations providing services to the elderly in the community) and resources supporting the elderly in the community" ( Gilmore, 2013: 9). It is important for professionals not only to have knowledge in this area, but also the ability to bring it closer and explain it to the elderly, in a way that will be understandable to them.

In essence, this is knowledge related to the process of mapping resources in the local community, but also at the state level, which can help meet the needs of the users they work with. According to Donevska: "Mapping can be done on all elements in the community, or on some of its selected fragments" (Donevska, 2006:
141). Mapping covers resources for all types of services necessary to meet the daily needs of the elderly starting from transport, meal preparation, healthy and proper nutrition, finance and management, availability and procurement of medicines, health facilities and services, social facilities protection and community social services, supportive living services.

In presenting services to customers, professionals should have the appropriate knowledge to adapt customers and families to the illness or condition of the elderly, and a particularly difficult task they have is to introduce long-term care services and hospices. Social workers around the world especially emphasize the need to talk about hospices very early, in the early stages of the disease, as many individuals end their lives without feeling the benefits it offers, precisely because users are accommodated there too late. Actually no one talks to users and their families about death and dying, and professionals involved in social intervention with the elderly are the only ones who have the courage to do so.

Knowledge for eligibility requirements for social and health care services. Professionals, in addition to having to know and have mapped the providers of social and health services in the environment, must also know what the conditions for using them are, or under what conditions the old person can be directed to use certain services, at certain providers. In these cases, it is important to know the exact type, scope and duration of the service, in order to make a proper 
connection between the needs of users and service providers.

Knowledge for protection from domestic violence and abuse. Professionals, when recognizing and identifying cases of abuse and domestic violence against the elderly in the family, must be well acquainted with the measures and mechanisms for protection from violence and abuse, as well as the institutions that are competent to take them, in order to act more adequately and to prevent more serious consequences from this situation.

Knowledge for providing psychosocial support to the elderly. Social intervention with the elderly has an auxiliary function and it includes professionals from other support professions. The social worker and the psychologist have a key role in providing psychosocial support to the elderly, and the lawyer also acts as a representative or advocate for the social rights of the elderly.

According to Travithick: "The word support is one of the most impressive words used in social work" (Trevithick, 2009: 203). According to Feltham and Dryden (1993): "It can mean almost anything from offering help, support, maintenance, reassurance, guidance, encouragement, validation, care, and love" (Ibid 1: p. 203). From here we can understand why the word support, primarily refers to the emotional support that a person gives to another, especially in times of stress or crisis. This support is especially important from professionals for the elderly, because with the support the elderly cope more easily with the situation and move on.
Psychosocial support is of great importance for every elderly person who for various reasons is in a state of social risk and is part of the services provided by professionals in social intervention with the elderly. Therefore, professionals involved in social intervention with the elderly must have knowledge that will provide adequate psychosocial support to the elderly. Therefore, advocacy and empowerment are two very commonly used techniques in social intervention with the elderly.

The empowerment of the elderly is done through their support and encouragement, and their motivation to take over and maintain control over their own lives. Stevenson and Parsloe (1993) use the term to refer to both "process and goals", but according to Clark (2000), the empowerment is much more used to describe that service users are gives "significant chance" and "available options" in order, as Thompson (2002) puts it, to provide greater control over their lives and their circumstances "(Trevithick, 2009: 219). The main focus of the empowerment is the ability to negotiate with the elderly, according to their conditions and internal capacities to identify the needs they express. Professionals must know how to empower the capacities of the elderly, because without knowledge of empowerment, they can begin to impose their own values in social intervention, without even being aware that it discourages the elderly. Imposing one's own values by professionals' means neglecting the 
personal values of elderly, which is not in line with practice.

A key element in empowerment is participation. Namely, people must be involved in making decisions that are related to their lives, in the process through which they can gain self-confidence, self-esteem and knowledge, and at the same time develop new abilities. However, participation alone is not enough. Apart from that, key elements in the model are: cooperation, learning and reflection.

"Nuzberg (1995) identifies a complex link between factors that negatively affect the well-being of the elderly, such as lack of resources, poor education, deteriorating health, and widespread egoistic attitudes. The model of empowerment in the practice of social work characterizes social workers as some who have the role of empowerers, who provide support and information, in the context of identifying the needs of the elderly "(Lynch, 2016: 108).

In the process of strengthening verbal communication requires a high level of awareness of professionals during the conversation with users, and paying special attention to what is offered as a ready answer. In fact, experienced professionals avoid offering ready-made answers to the user, because with experience they know that each user is a story for themselves and everyone should have an individual approach, because no matter how many users are in the same or similar situation, it does not mean that what has worked for one user must work for others. For these reasons, professionals avoid advising and giving suggestions and solutions ahead of time. That is why the professionals in communication with the users focus on the use of the technique for empowerment of the users, as a methodical process and goal of the social intervention, which enables the provision of a high level of psychosocial support.

In empowerment, it does not matter who transfers power to whom, it is only important to be aware and understand its existence. According to Thompson (2001): "The nature of empowerment is to support the elderly in empowering themselves" (Lynch, 2016: 108). A social worker who adheres to the principles of empowerment takes on three roles:

- "Above all, it advises the parties how to find potential support in the family, the local community, etc. This refers to the activation of the party itself;

- Teaches clients to become sensitive to the appearance of their own helplessness. Impotence is the result of personal incompetence in social or emotional functioning. According to the concept of empowerment, knowledge related to personal shortcomings should be developed and programs should be made for their remediation or appropriate communication;

- The third role of the social worker is the role of a teacher. It is considered that control over one's environment requires certain knowledge and skills. The individual or group that has problems with establishing proper relations with their environment, must know the reasons that led to it, must know the 
rights and means that enable it to act effectively."

(Donevska, 2014: 161)

Advocacy is a particularly important technique for every professional. The use of advocacy is as important as it is for the professional to convey the voice of the user whose needs need to be met in social intervention. Advocacy involves speaking and acting in the best interests of the elderly.

Advocacy in all its forms aims to ensure that people, especially those most vulnerable in society, can:

- "To hear their voice on issues that are important to them.

- To defend and protect their rights.

- Their attitudes and desires are really taken into account when making decisions about their lives."

(Advocacy, https://www.seap.org.uk/imlooking-for-help-or-support/whatis-advocacy.html)

Advocacy, as a process of support, enables people to express above all their views and concerns and provides them with access to the necessary information and services. By advocating for the elderly, professionals simply defend and promote their rights and responsibilities.

The main focus of the social worker is the well-being of people, families and communities. Therefore, it is crucial for professionals, especially for social workers in the social intervention with the elderly, to act as advocates. Advocacy ac- cording to Thompson (Thompson, 2002) includes: "Representing the interests of others when they are unable to do so for themselves" (Trevithick, 2009: 232). Through advocacy, professionals protect vulnerable users and provide conditions for their best interests to be upheld. Social workers represent the elderly in exercising their rights to health and social care, up to cases of exercising basic human rights. Advocacy is especially important in cases of social intervention with the elderly who have cognitive loss.

"Advocacy can involve speaking, writing, acting, or arguing on behalf of others" (Trevithick, 2009: 233). An advocate is one who provides support for user advocacy, whenever he or she needs it. "The advocate can help you get the information you need or go with you to meetings or interviews, in a supportive role" (Advocacy, https://www.seap.org. uk/im-looking-for-help- or-support / what-is-advocacy.html).

Professionals that advocate the elderly can perform a variety of tasks in the role of advocates, from writing letters, requests, etc., to talking about and on behalf of the user, if the user cannot do it alone.

On the other hand, social workers represent the elderly and their families in team meetings, and get involved in the micro level, but it is not uncommon for them to represent the elderly in front of their families, because often their families, or their family members have different thoughts about what is best for their loved ones. In such situations, the advocacy skills of professionals are very important, 
because it may not be so important what their families want, but what the elderly want and need. In these cases when professionals see that the elderly have a problem with the personal needs and desires of their families, advocating for the interests of the elderly is an important tool for professionals.

"Advocacy aims to ensure that the voices and interests of service users are heard and responded to in ways that influence the attitudes, policies, practices and delivery of services" (Ibid 1: p. 233).

Social workers in certain cases are obliged even by law to represent the elderly in exercising their rights, especially in cases of abuse of the elderly, when reporting any suspicions by the relevant authorities.

Professionals working in social intervention with the elderly, as well as many NGOs and associations, often act as intermediaries between marginalized groups and decision makers. Using the advocacy technique, they give a voice to their members and target groups.

\section{RESEARCH RESULTS}

The research of the knowledge of the professionals for social and health protection of the elderly is a complex area, therefore the research was realized with the professionals and the elderly. The purpose of this approach is on the one hand to see the need of the elderly for social and health support, and on the other hand to see the knowledge available to professionals for social and health care of the elderly, to provide adequate support to the elderly. Through this approach, an assessment should be made of the need to strengthen the knowledge that should enrich the programs for continuing education of professionals involved in social intervention with the elderly. The research was conducted in the second half of March and the first half of April 2019.

\subsection{RESEARCH OF THE KNOWLEDGE OF THE PROFESSIONALS FOR SOCIAL AND HEALTH CARE OF THE ELDERLY}

The survey questionnaire for professionals covers 61 professionals, of which 35 professionals are employed in institutions for un-family care for the elderly (blue), or all professionals from institutions for un-family care for the elderly, who at the time of the research were licensed (work permit) from the Ministry of Labour and Social Policy. Of the other professionals, 21 are employed in the centres for social work (green): Inter-municipal centre for social work Skopje, Inter-municipal centre for social work Ohrid, Inter-municipal centre for social work Bitola, Inter-municipal centre for social work Debar, Inter-municipal centre for social work Berovo, Inter-municipal centre for social work social work Kumanovo and Centre for social work Resen. From the organizations (associations) that provide services in the home and community services, the research includes 5 professionals (grey) from: the Association for Support and Development "Humanity", the Red Cross of the City of Skopje, the 
Red Cross of the Municipality of Saraj, the Red Cross of the Municipality of Cair and the Red Cross of the Municipality of Gazi sionals working in the centres for social work (green), but in the area of social protection of the elderly and realization

Graph number 1. Respondents (professionals) by type of institution in which they work

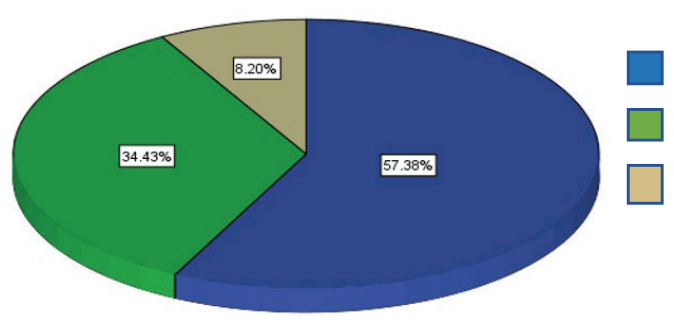

Baba. The participation of professionals in the research, according to the type of institution in which they work graphically is shown in Graph number 1.

According to the data, professionals employed in institutions for un-family social protection of the elderly (institutions for social protection of the elderly) account for $57.4 \%$ of the research sample (blue), and provide services that include accommodation and 24-hour care and services for the elderly, $34.4 \%$ are profes-
Public institution for social protection of older people

Center for Social Work

Ngo providing services for older people

of rights and services for the elderly at risk and 8.2\% (grey) are professionals working in associations and organizations that provide services home and community services (NGO providing services for the elderly). It is important to note that at the time of the research, there is still no legal obligation to license home and community service providers, and thus professionals employed by home and community service providers are not covered by the process of licensing of

\section{Graph number 2. Respondents (professionals) by professional profile}

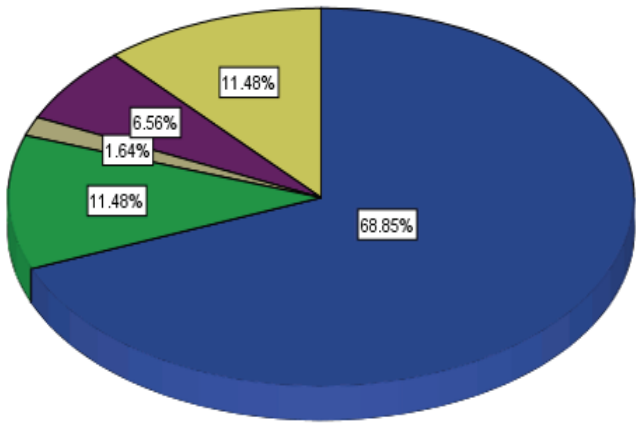

Legend:

blue - social workers

green - psychologists

grey - physicians

violet - nurses

yellow - lawyers 
professional workers and their continuous professional development.

According to the data in Graph 2, most of the professionals, $69 \%$ or 42 professionals by profession are social workers (blue), which is a key profession in social intervention with the elderly, because social workers are those who are providers of social services and work with the users from the reception phase, through the assessment and planning, to the act of providing the service, as well as connecting with their families and all necessary stakeholders, or resources in the environment, so that the services are in accordance with the needs of users, in the case with the needs of elderly. The data show that the research includes other professionals who have a significant role in social intervention with the elderly and $11.5 \%$ are psychologists (green), with the same percentage of $11.5 \%$ covered by lawyers (yellow), with $6.6 \%$ nurses (violet) and $1.6 \%$ physicians (grey). The low representation of nurses and doctors involvement, especially in nursing homes and home services.

The knowledge of professionals for professional performance of work tasks in the provision of social services for the elderly, is an important starting point for their professional engagement in this area of social work. For the needs and the main purpose of this research, the professionals were asked to state whether during the higher education they had subjects whereby they acquired knowledge for social intervention with the elderly. The results of the answer to this question are shown in Table 1, where it can be seen that out of a total of 61 professionals, only $42.6 \%$ had courses e whereby they acquired certain knowledge about social intervention with the elderly, and 57, 4\% did not have items of this nature. These data impose the need for a deeper study of the issue of ways that could increase the willingness of professionals to provide social services for the elderly, given that the population in the world and in the

\section{Table number 1. Courses for acquiring knowledge for working with the elderly}

\begin{tabular}{lcccc}
\hline \hline & Frequency & Percentage & Valid Percentage & Cumulative Percentage \\
\hline No & 35 & 57.4 & 57.4 & 57.4 \\
Yes & 26 & 42.6 & 42.6 & 100.0 \\
All & 61 & 100.0 & 100.0 & \\
\hline \hline
\end{tabular}

as professionals with higher education reflects their minimal involvement in social services for the elderly, which leaves open the question of their more intensive
Republic of North Macedonia is aging, on the other hand, due to changes in family structures, the elderly are increasingly in need of social services. 
Social work, as a supportive profession for people at social risk, offers a number of services. It covers all categories of users and all age groups, including the elderly. Therefore, in the education of professionals who are later expected to engage in social intervention with the elderly, as users of services, courses must be planned, whereby professionals will gain basic gerontological and geriatric knowledge and within which they will attend practice in which they will develop basic skills to be prepared to work with the elderly.

The need for knowledge and skills to work with the elderly stems not only from the specificity of the category of users, but from the specifics of age as a stage of the life cycle and aging as a process, but also from the numerous changes in the social environment that age brings. On the other hand, in the modern way of life, the elderly and their needs are changing more and more, so are and the approaches and services that professionals should use in working with the elderly. Having in mind that 2020 will be especially remembered after the pandemic with COVID-19, in this part special attention is paid to the knowledge of professionals needed for social and health care of the elderly.

For the level of knowledge of professionals, related to resources and services for social and health care, which are often interconnected and given together, because with age there is a decline in the vitality of the organism, according to the data in Graph Number 3, 41\% (first column) from the professionals they consider that they have insufficient knowledge, or they consider that they do not know the forms of social and health care and the resources that provide the social and health care services. Another $27.9 \%$ (second column) of professionals believe that they have basic knowledge from this group, but their knowledge should be strengthened. The remaining $31 \%$ of professionals believe that they have sufficient knowledge of this group. This means that only $31 \%$

\section{Graph number 3. Level of knowledge of professionals for social and health care of the elderly}

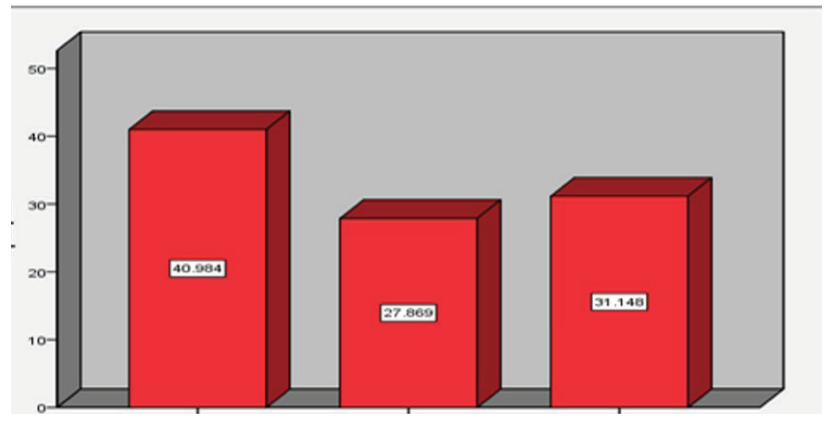

Percentage
Legend:

first column (40,9\%) - insufficient knowledge second column (27.8\%) - basic knowledge third column $(31,1 \%)$ - sufficient knowledge 
of professionals do not need additional knowledge in this area, while the remaining 69\% need knowledge enhancement and even $41 \%$ have a high level of need for knowledge enhancement in this group, because they have insufficient knowledge. The reason for this situation with this group of knowledge may be the undeveloped resources for support at the local level, but this cannot be an excuse for not knowing the resources that exist, as well as the type of services they provide and the establishment of cooperation with them.

Behind the level of knowledge of professionals for social and health care of the elderly, through frequency statistics (type of knowledge by scoring), a review of the types of knowledge in the group was made, and it can be concluded that the knowledge of: mapping health services and care, mapping of social services and care, conditions for using services, psychosocial support of the elderly, rights and services from social protection and protection from domestic violence and abuse range in frequency from 150 to 200 , from maximum 250. Professionals said they had the least knowledge about protecting the elderly from domestic violence and abuse, and the most about mapping health services.

\subsection{RESEARCH OF THE NEEDS OF ELDERLY PEOPLE FOR SOCIAL AND HEALTH SUPPORT}

In order to determine the level of need for support of the elderly involved in social intervention and the connection between the support and the need to strengthen the knowledge of professionals, the research also includes a sample of elderly people receiving social services in institutions for un-family care, as well as elderly users of home or community services.

The survey questionnaire for the elderly covers 70 elderly people, of which 54 elderly people are users of services in public and private institutions for un-family social protection of the elderly: PISP "Ruski" - Kadino, PCI Home for the elderly "Kiro Krstevski Platnik" - Prilep, PCI Home for the elderly" Zafir Saito "- Kumanovo, and 16 elderly people beneficiaries of services in the home and services in the Red Cross of the city of Skopje, Red Cross of the Municipality of Cair, Red Cross of the Municipality of Saraj and the Red Cross of the Municipality of Gazi Baba and the Association for Support and Development "Humanity".

The coverage of the elderly with this research is shown in Graph 4. The data show that the research covers 70 elderly people, of which $77.1 \%$ (blue) are users of institutional or un-family care services and $22.9 \%$ (green) are users of non-institutional care services or home services and community services. This ratio of elderly people included in the research according to the type of services they use is a result of the greater development of institutions for un-family social protection in relation to home and community services in the Republic of North Macedonia.

In the Republic of North Macedonia, the elderly have much more opportunities to use institutional care services, as opposed to home and community services, as the resources for these service providers 


\section{Graph number 4. Respondents (elderly people) by type of services they use}

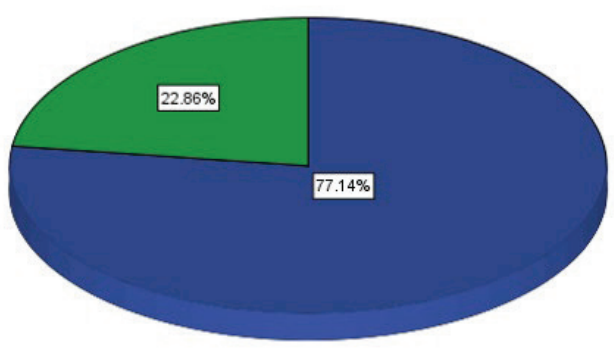

are not yet developed, but the reforms in the social protection system and the introduction of Licensed and authorized social service providers are expected to contribute to the development of home and community services.

That the elderly in the Republic of North Macedonia have an unsatisfied need for support with social services, show the results of some previous researches in our country, so they are used to compare with the results obtained in this research, in the direction of considering the need to raise the quality and quantity of social services for the elderly.

For the needs of this research, in the questionnaire for assessment of the needs for support of the elderly, groups of questions were made that should assess the need for health support of the elderly and the need for social support.

After processing and grouping the data for assessment of the need for health support (questions 5 to 11), the results shown in Graph 5 are obtained, which indicate that as many as $77.1 \%$ of the elderly need health support First and second column together), but on different level, or that blue $(77.14 \%)$ - institutional care services green $(22.86 \%)$ - non-institutional care services or home services and community services

$41.4 \%$ of the elderly need health support (second column), but $35.7 \%$ need it very much (first column). This means that more than three quarters of the elderly need some level of health support, while only $22.9 \%$ (third column) of the elderly do not need health support. That the elderly need health support is confirmed in the research from 2017, but: "The distance of the health institution is the most common reason for not visiting a doctor for the elderly from Polog (24.2\%) and the Northeast region (19.2\% ) “. (Dimitrijoska, S., Stanojkovska, D., 2017: 40). The results of both studies show that the elderly need health support, but the question arises: Does everyone receive it and to what extent?

To determine the level of need for health support, important is the answer to the question: Who cares for the elderly during their illness? From the questionnaire for assessing the needs of the elderly involved in social intervention, shown in Table 2, from where according to the frequencies it is seen that in over $18 \%$ of the cases the spouse takes care of them mostly during the illness, in $17 \%$ of the cases they are taken care of by their neighbours, in 
Graph number 5. Level of need for health support of the elderly

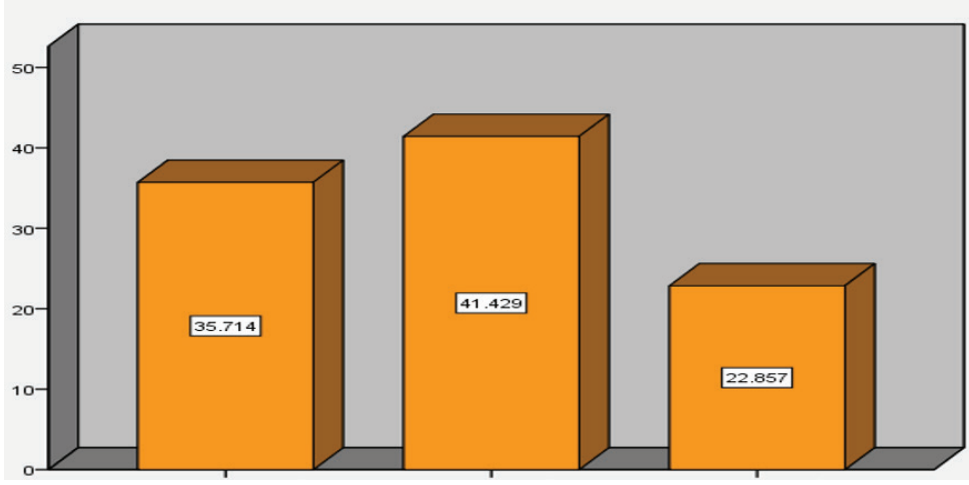

first column $(35,714 \%)$ insufficient need second column $(41,429)$ have a need third column $(22,857 \%)$ - do not have a need

Percentage

about $13 \%$ of the cases their children and with the same percentage (13) declared themselves relatives. These are the results that speak of the informal support that the elderly receive during illness from the closest ones in the environment in which they live, while about $27 \%$ stated that when they are sick they are cared for by a professional team at $14,3 \%$ of institutional protection, which means that these persons are placed in institutions for un-family protection and are taken care of

Table number 2. Caring for the elderly during illness

\begin{tabular}{lrrrr}
\hline \hline & F & Percentag & & Valid \\
& & e & $\begin{array}{r}\text { Cumulative } \\
\text { Percentage }\end{array}$ \\
\hline Spouse & 13 & 18.6 & 18.6 & 18.6 \\
Children & 9 & 12.9 & 12.9 & 31.4 \\
Relatives & 9 & 12.9 & 12.9 & 44.3 \\
Neighbours & 12 & 17.1 & 17.1 & 61.4 \\
Friends & 2 & 2.9 & 2.9 & 64.3 \\
Paid support from another person & 6 & 8.6 & 8.6 & 72.9 \\
$\begin{array}{l}\text { Professional team from institutional } \\
\text { care }\end{array}$ & 10 & 14.3 & 14.3 & 87.1 \\
$\begin{array}{l}\text { Professional team from non - } \\
\text { institutional care }\end{array}$ & 9 & 12.9 & 12.9 & 100.0 \\
All & 70 & 100.0 & 100.0 & \\
\hline \hline
\end{tabular}


by the team working in this institution. $12.9 \%$ of the elderly in this research stated that in case of illness they are cared for by an expert team from non-institutional care, which means that these people are beneficiaries of home or community services. In $8.6 \%$ of cases, the person who takes care of them during the illness is paid. The answers to this question also depend on the recent experiences of the elderly involved in social intervention during the illness, or who took care of them while they were ill.

Similar to the results of this research are the results of the research from 2017, which show that: "To the question who usually takes care of the elderly person while he is ill, most of them i.e. $39.8 \%$ answered a spouse, then the children he/ she lives with $33,7 \%$, and the children who come to help $12.9 \%$ of the respond- ents" (Dimitrijoska, S., Stanojkovska, D., 2017: 35).

With deteriorating health, the elderly not only need care and attention where they live, but also need additional consultative examinations with a certain type of doctors - specialists, whose opinion is crucial for the health care and care that should get the old person, through a professional team of nurses and caregivers. Therefore, the research covers the type of needs of the elderly for health support from a doctor and the type of needs for health support from a nurse. From the 2017 survey: "For health care by a doctor and a nurse, as much as $17 \%$ of the elderly said that they need it a lot, and $16.2 \%$ that they need it moderately" (Ibid 1: p. 75).

Graph Number 6 shows the frequencies for the need for health support from a doctor, or what kind of doctor or specialist is mostly needed for health support of the

\section{Graph number 6. Need for health support of the elderly from a doctor}

\section{Legend:}

first bar - accommodation in a health institution $(11,43)$ second bar - examinations by another specialist $(12,86)$ third bar- examinations by neurologist $(4,286)$ fourth bar - examinations by cardiologist (20) fifth bar - examinations by internist $(14,29)$ sixth bar - examinations by a psychiatrist $(11,43)$ seventh bar - examinations by general practitioner (15.7)

eight bar - consultation with a doctor (10)

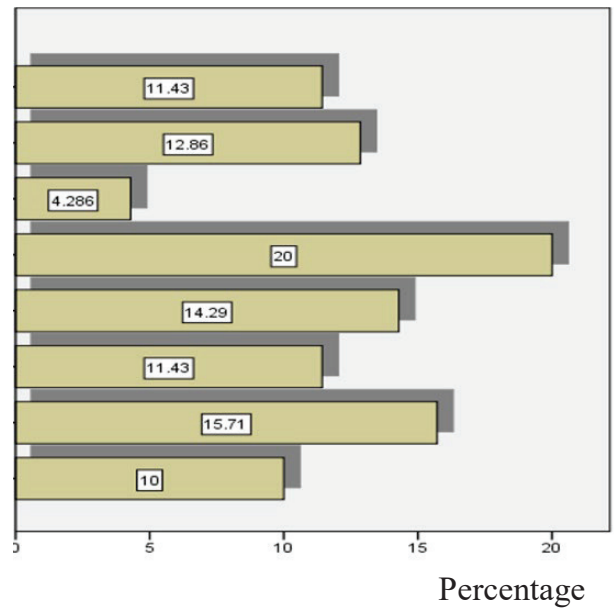




\section{Graph number 7. Type of need for health support of the elderly from a nurse}

\section{Legend:}

first bar - giving and control of tablet therapy $(37,14)$

second bar - giving ampoule and intravenous therapy (30)

third bar - control of the health condition $(32,86)$

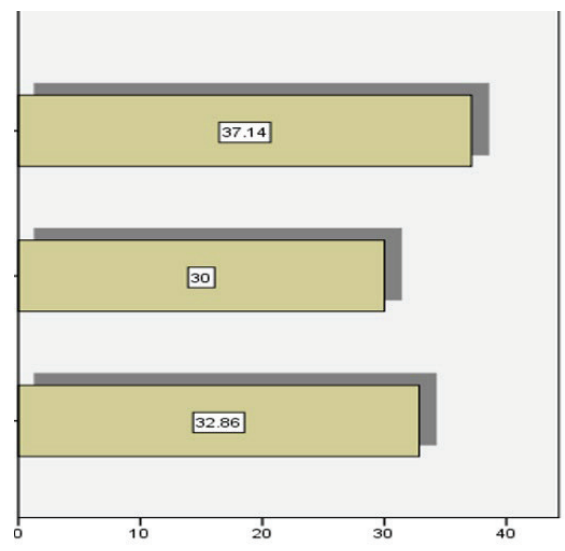

Percentage elderly. These data show that the elderly, most $(20 \%)$ need examinations by a cardiologist, general practitioner $15.7 \%$, and internist $14.3 \%$. It is also interesting to note that $11.43 \%$ of the elderly included in this research, who are involved in social intervention, need accommodation in a health institution. This speaks to the need for a broader multidisciplinary approach to social intervention, which is recognized by the need to involve physicians with different specializations. This need is in line with the reforms of the social protection system which enables the conclusion of agreements between social and health institutions, as well as the development of institutions for un-family protection, as homes for help and care.

Graph 7 shows the frequencies for the type of need for health support from a nurse. It shows that in $37.14 \%$ the service from a nurse is needed due to giving and control of tablet therapy, in $30 \%$ due to giving ampoule and intravenous therapy and in $32.9 \%$ due to control of the health condition, which speaks of high level of need for nurse support. The nurse is the one in charge of the routine medical examinations, pressure, blood, therapy (tablet, muscle, intravenous), but also who best sees the changes in the elderly due to the frequent direct contact with them. And the results of the survey from 2017 show that: "Regarding the services they receive from the patronage service, the largest number of elderly people stated that it is a measurement of blood pressure, $51.8 \%$, and $11 \%$ of the elderly answered that it is measuring sugar, some of them received infusion and fat testing "(Dimitrijoska, S., Stanojkovska, D., 2017: 42), while in terms of the necessary assistance in proper and timely taking of drugs:" $12.2 \%$ are very much needed, and $9.2 \%$ need it moderately "(Ibid 1: p.75). 


\section{Graph number 8. Level of need for social support of the elderly}

Legend:

first column $(35,714)$ - insufficient need second column $(42,857)$ - have a need third column $(21,429)$ - do not have a need

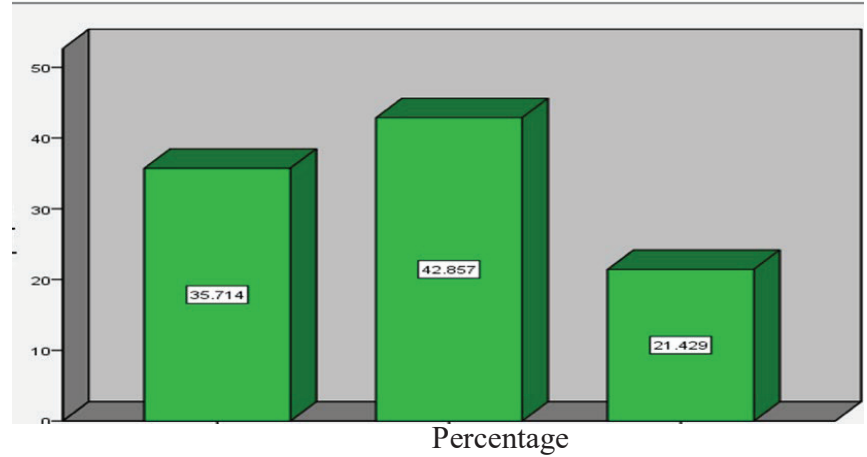

Social support refers to all those activities or work tasks that the social worker has in the implementation of the social intervention with the elderly person. After processing and classifying the data from the group of questions related to the assessment of the need for social support of the elderly involved in social intervention, we obtained the results shown in Graph Number 8.
From the data in Graph 8, it can be seen that $78.7 \%$ of the elderly involved in social intervention need social support on two levels: about $43 \%$ need social support (second column), and others $35.7 \%$ (firs column) need it to the extent of necessity. Only $21.4 \%$ of the respondents (elderly) stated that they do not need social support (third column). This shows that more than three quarters of the elderly also need social support.

\section{Graph number 9. Type of necessary support for the elderly from a social worker}

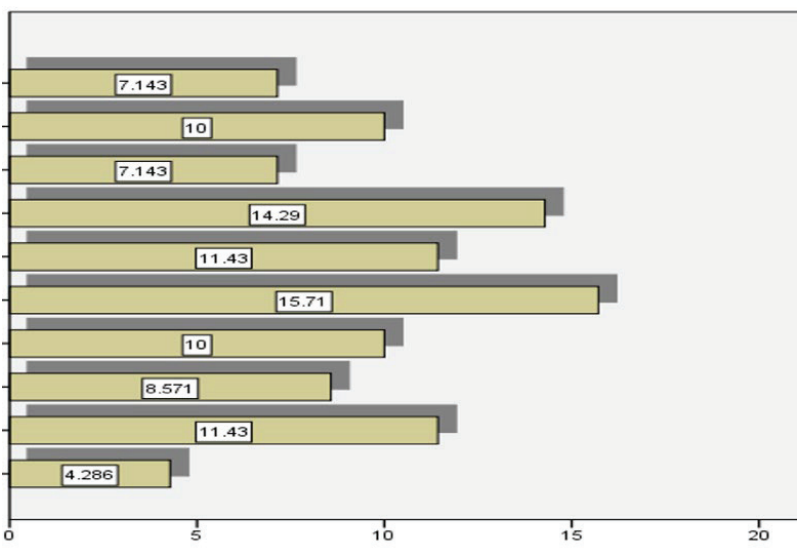

Legend:

1st bar - support from NGOs $(7,143)$

$2^{\text {nd }}$ bar - physical activity (10)

$3^{\text {rd }}$ bar - nutrition $(7,143)$

$4^{\text {th }}$ bar - support $(14,29)$

$5^{\text {th }}$ bar - exercise of rights $(11,43)$

$6^{\text {th }}$ bar - volunteer work $(15,71)$

$7^{\text {th }}$ bar - cultural and entertainment activities

(10)

$8^{\text {th }}$ bar - education $(8,571)$

$9^{\text {th }}$ bar - counselling $(11,43)$

$10^{\text {th }}$ bar - daily stay $(4,286)$

Percentage 
The essence of the activities carried out by the social worker in the social intervention with the elderly is on the one hand to enable them to exercise certain rights and services of social protection, but also to help maintain social contacts and social activity of the elderly, which will raise their self-esteem and help maintain their physical and mental health. The social worker can achieve all this through the realization of exercises for physical activity, psychosocial support, counselling on certain topics of social functioning, education, activities for cultural and entertainment life, accompanying the old person to meet certain needs in the social environment, providing nutrition or day care, providing some support from some associations and organizations that provide social protection services and the like.

The data shown in Graph 9, show that social workers are mostly required to pro- vide the elderly with volunteer engagement (15.7\%), followed by support for their family members $(14,29 \%)$, and with support in exercising social protection rights and counselling (11.43\%) as well as education on certain topics of everyday life $(8.57 \%)$.

In the social intervention with the elderly, carers and / or geronto housewives also have an important role, which depending on the form of social protection play an important role in performing daily activities for and with the elderly. They are the ones who work most directly in meeting the basic necessities of life, from maintaining personal hygiene of the old person, hygiene of the bed and clothes, procurement of groceries, preparation of food, payment of bills, accompaniment of certain events and the like. According to the data in Graph 10, the elderly caregivers / geronto housewives need the most

\section{Graph 10. Type of required elderly support from a caregiver / geronto housewife}
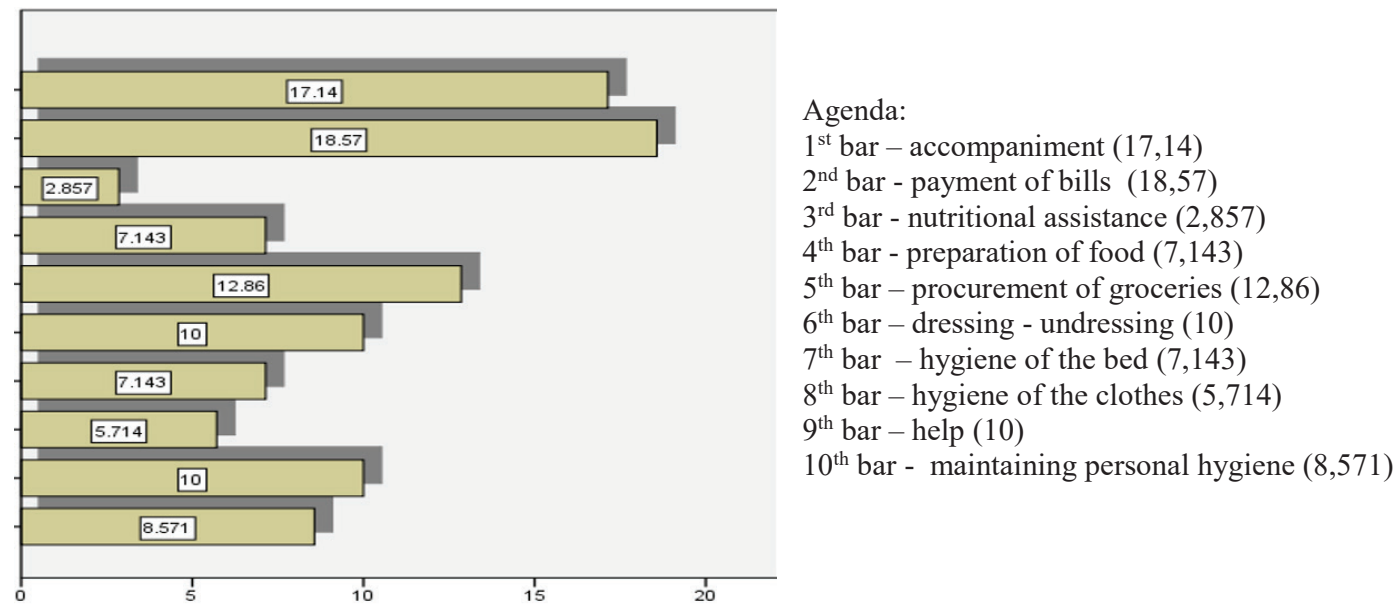

Percentage 
support for payment of bills $18.57 \%$ and escort $17.14 \% .12 .86 \%$ need assistance in purchasing groceries, and $10 \%$ need assistance in dressing and undressing and with the same percentage (10\%) stated the need for maintenance, and assistance in maintaining personal hygiene. The necessity of these social services for the elderly is confirmed in the survey from 2017, as follows: " $15.9 \%$ of the elderly surveyed said that they need the grocery service and $11.9 \%$ that it is moderate required; $12.7 \%$ think that they really need the food preparation service, and $11.9 \%$ that they need it moderately; $9.4 \%$ of the respondents are in dire need of nutritional assistance, and $7.2 \%$ of the respondents are moderately in need; $6 \%$ of the elderly are in dire need of help getting dressed / undressed, and $8.8 \%$ of the elderly are moderately in need; for maintaining personal hygiene, $9.8 \%$ of the elderly stated that they need help a lot, and $10.7 \%$ that they need help moderately; $11.1 \%$ of the elderly need a lot of help to maintain bed hygiene and the same number of elderly people need this help moderately; $12.6 \%$ need assistance in maintaining clothing hygiene, and $11.2 \%$ moderately need assistance in maintaining clothing hygiene; $35.6 \%$ of the elderly need the accompaniment when visiting a specialist doctor, hospitals, etc., while $17.6 \%$ need the help for this service a lot, and $15.1 \%$ need it moderately "(Dimitrijoska, S., Stanojkovska, D., 2017: 73-76).

\section{SOCIAL SERVICES FOR THE ELDERLY IN THE REPUBLIC OF NORTHERN MACEDONIA AT THE TIME OF COVID - 19}

The situation with the pandemic COVID - 19 caused changes and restrictions on social and health care services intended for the elderly. Through desk analysis of information obtained from the institutions for un-family care of the elderly, it can be concluded that the institutions were not prepared to deal with the pandemic, but faced the challenges step by step faced and adapted to the new situation.

The introduction of the state of emergency and the restriction of movement was initially the biggest problem, due to the inability of the employees in the institutions to get to their jobs. Institutions, in order to provide timely and continuous services for the elderly, organized transportation for the employees to the workplace. The employees were organized in teams that worked 7/10/14 days in the institution, without leaving home and without replacement within the specified period.

Another challenge was the procurement of masks, protective gloves, protective suits, equipment and disinfectants, especially at the beginning of the pandemic when these resources were limited. Access to procurement of medical devices and medicines is initially limited due to the limited working hours of the institutions. In the institutions where there were opportunities, the users, through work and volunteer engagement, made masks 
independently, for the needs of the institution. All institutions acted in accordance with the recommendations of the Ministry of Health.

In terms of users, the biggest challenge for them was the introduction of a visit ban, which replaced live contacts with family members with video or telephone contacts. Regarding the services in the institutions themselves, they continued to be provided 24 hours as before, but with increased protection measures and a change in the methodological approach, group social work and social contacts between users, were reduced exclusively to individual work of employees with users.

Another challenge, which was a kind of restriction of social services in institutions for un-family care for new beneficiaries, is the ban on admission of new beneficiaries, which was introduced by almost all institutions for un-family protection of the elderly and which in some institutions lasted until the adoption of Protocols that were prepared in cooperation with the Centres for Public Health. Institutions that gradually loosen the ban on admission of new users, when accepting new users, require a PSR test, not older than 72 hours and new users are placed in special isolation rooms, with quarantine measures lasting 14 days.

As the elderly are more susceptible to infections and viruses, very often the seasonal flu or other illnesses of the beneficiaries in the institutions for social protection of the elderly imposed conditions of isolation and transport to the institutions of health care, which was limited only to urgent needs from health care.

The elderly living in their own homes had very few resources in the community, which enabled them social services, during COVID - 19. The Red Cross of the City of Skopje and the Association for Support and Development Humanity, were among the few organizations that provided them with food and groceries, medicines, and other necessities for the life of the elderly, and distributed them to their homes. Many elderly people on the entire territory of the Republic of North Macedonia had to manage individually in terms of procurement of groceries in conditions of limited movement and COVID - 19.

In terms of health care, all appointments in the system my appointment were cancelled, and hospitals prepared to respond to the challenges of COVID-19. Thus many current, chronic conditions in the elderly were not a priority under COVID-19, and health services were available only in emergencies.

\section{CONCLUSION WITH RECOMMENDATIONS}

The research of the knowledge of the professionals for the social and health protection of the elderly, shows the increase need of its enhancement, as $69 \%$ of the respondents have emphasized such need. $41 \%$ of them have a high level of need to strengthen knowledge in this group, because they have insufficient knowledge. 
On the other hand, the research showed that the elderly have an increased need for social and health support, $77.1 \%$ of the elderly need health support ( $41.4 \%$ of the elderly need health support, and $35.7 \%$ $\%$ need it very much) and $78.7 \%$ of the elderly need social support $(43 \%$ need social support, and others $35.7 \%$ need it to the extent of necessity).

The occurrence of a pandemic with COVID - 19, indicated the weakness of the system in the Republic of North Macedonia, namely the disconnection of social and health services for the elderly. The absence of Protocols for dealing with pandemics and crisis situations, the lack of networking of social and health resources in the community, ignorance of the institutions and services they provide, as well as the non-development of services in the home and community affected the quality and quantity of social and health services.

These three conditions inevitably impose the need to empower the knowledge of social and health care professionals for the elderly, including the knowledge to act in times of crisis and epidemics. Enriching the content of the Programmes for continuous professional development with content on this topic is one of the ways to strengthen the knowledge of professionals.

\section{BIBLIOGRAFY}

Advocacy, [Online], Available from: https://www.seap.org.uk/im- looking-for-help-or-support/what-is-advocacy.html) [Accessed in May, 2019]

Димитријоска, С., Станојковска, Д., (2017) Анализа од спроведено истражување на тема: „Потреба од социјални и од здравствени сервиси за старите лица“ Црвен крст на Република Македонија, Здружение за унапредување на условите за грижа и сместување стари и изнемогнати лица Хуманост

Доневска, М., (2006), Социјалната работа во локалната заедница, Филозофски факултет - Скопје

Доневска, М., (2014) Теоретските основи на социјалната работа, Филозофски факултет - Скопје.

Gilmore, R. L., (2013) Motivations, Skills and Rewards: Social Worker`s Perspectives on Practise with Older Adults, Master of Social Work Clinical Research Papers, Minnesota (No date) [Online], Available from: https://sophia.stkate.edu/cgi/viewcontent.cgi?arti$\mathrm{cle}=1181 \&$ context $=\mathrm{msw}$ papers [Accessed on 5 May, 2016]

Lynch, (Linc), R., (2016) Praksa socijalnog rada sa starima: Pozitivan pristup centriran ka osobi, Fakultet politickih nauka, Univerzitet u Beogradu

Oxford Dictionary of English (2010) Oxford University Press, Third Edition

Trevithick, P., (2009), Social Work Skills: A practice handbook, second edition, Open University Press 